\title{
Empirical Analysis of Investments on the Fine Art Market
}

\author{
Anna Zhukova*, Valeriya Lakshina $^{\dagger}$, Liudmila Leonova ${ }^{\ddagger}$ \\ ASE EC JSC, Nizhny Novgorod, Russian Federation \\ *vodopianovaana@yandex.ru \\ ${ }_{\dagger}$ National Research University Higher School of Economics, Nizhny Novgorod, Russian Federation \\ †vlakshina@hse.ru, ${ }^{\ddagger} l$ leonova@hse.ru
}

\begin{abstract}
The instability of the stock market spurs investors to seek alternative ways of allocating financial resources. In this case, art assets could be considered as an attractive investment. Due to the uniqueness, specific costs, and risks inherent to the artworks, the fine art market is very heterogeneous and needs special treatment. In this article, we investigate attractiveness of the fine art market for investors in several ways. First, we construct hedonic art price indexes using the time dummy variable method based on the quantile regression. Secondly, we assess the art assets risk through CAPM model. Data include 536660 observations about oil paintings on auctions around the world during 2005-2015. According to the estimation results, the postwar paintings sold in the high price sector could be considered as an attractive sector for the investors but its acquisition is accompanied by a relatively high risk compared to the operation on the stock market.
\end{abstract}

Index Terms-investment decisions, fine art market, hedonic art price index, fine art investment risk

\section{INTRODUCTION}

Among reasons, which warm up the interest to the fine art market, are acknowledgment of the social status, aesthetic pleasure and acquisition of the potential investment asset. Traditionally, collectors were main participants of the fine art market. But in the last thirteen years buyers are paying more attention to the profits obtained from investing in the art. The world auction's revenue has increased almost three times from $\$ 4.15 b n$ in 2005 to $\$ 11.2 b n$ in $2017^{1}$. Such indicators as number of million dollars lots and bought-in rate ${ }^{2}$ also indicate the positive trends on the market: in 2013 the number of million dollars sales achieved 1519 lots compared to 487 lots in 2005; the bought-in rate keeps the level of $30-35 \%$. Moreover China has replaced the USA from the leader's position despite the fact that the USA along with the UK have been predominating on the global fine art market for more than 50 years. The largest art sector is the modern art: it takes more than a half of the market in terms of revenue generated by public sales.

In the paper we consider data from the fine art auctions presented on https://www.Artsalesindex.artinfo.com Almost all auctions, which operate on the fine art market, are English auctions. In an English auction the bidding starts at the minimum bid and then participants raise their bids. When the bidding stops, an item is sold at the highest price bid, which is called hammer price. If the hammer price is less than the reserve price which is set by the seller, the item

${ }^{1}$ https://www.theartnewspaper.com/news/global-auction-sales-up-25-in-2017

${ }^{2}$ The percentage of unsold items. goes unsold. Auctioneers and sellers usually keep the reserve price secret,notwithstanding there is evidence that it is not an optimal strategy [1]. The reserve price of items is considered to be a little bit less than their low auction's estimation (about $70 \%$ of the low estimation). Among other researchers [2] proved this suggestion.

The high and low estimations for each item are published in an auction's presales catalogs. It is worth mentioning that both the theory and empirical studies confirm the rightfulness of these estimations. The auction house receives commissions from both the buyer and the seller. The buyer's premium is 10$25 \%$ of the hammer price; it is one of the main instruments of competition between auction houses [3]. However, the buyer's premium could be much smaller for the institutional investors. The seller's commission varies from 5 to $10 \%$ of the sale price and could be negotiable.

The fine art market would be characterized by certain effects. Firstly, the unsold item is called burned, and some auction houses do not permit owners to sell such item immediately after the unsuccessful auction due to the belief that the failure causes price decrease. [4] argue that an unsold artwork loses $\frac{1}{3}$ of its final price at re-selling. Secondly, the effect of "masterpiece" implies that, as a rule, dealers recommend to buy one "masterpiece" for $\$ 100000$ than 10 art works for $\$ 10000$. However, this effect is doubtful, for example, [5] did not find any supporting evidence for this effect. Thirdly, there is a hypothesis about an indirect impact of the stock market on the art market via the welfare of their players - the effect of "welfare" [6]. And finally, according to the anchoring effect, past prices or auctions estimations of the item could influence the buyer's and seller's perceptions of the real value of an item what is reflected on the sale and reserve prices respectively [7].

Art is considered as alternative asset and tool for portfolio diversification [8]

At the same time, high transaction costs for acquisition and storage (auction's commission, transportation and storage costs, customs fee) along with the specific risks (theft, fire, forgery) are the factors which determine lower yield compared to securities [9], [10]. On the other hand, [11], [12] provide evidence of a relatively high art market return along with a moderate risk. Such a controversial findings motivate researches to conduct more comprehensive analysis of investments on the fine art market, taking into account the high level of heterogeneity on this market. 
In this article we focus on analyzing the heterogeneity of the fine art market, comparing it with stock market and evaluating fine art investment risks. To achieve this we employ quantile regression to estimate the hedonic art price index and assess fine art investments risk by means of capital asset pricing model. The analysis is conducted for each fine art sector separately as suggested in, for example, [8].

We come to the conclusion that the art market is characterized by relatively high return and risk. From the investor's standpoint the most attractive sectors of the market are modern and postwar art, especially, paintings with high sale price. The inference also supports the widespread belief that the contemporary art sector is subject to speculations. Expensive impressionists' paintings are of interest among investors who prefer a relatively low risk along with a moderate return. The results also show that the old masters' works could not be considered as a successful investment.

The rest of the article is organized as follows. Section II describes the data, Section III explains the methodology employed in the research, Section IV discusses empirical results and Section V concludes.

\section{DATA DESCRIPTION}

Data for the study has been collected from http: //artsalesindex.artinfo.com/ website using the MATLAB software. Our sample contains 536660 observations about oil paintings on auctions around the world during 2005-2015. The collected information includes author's name, nationality and date of birth; auction date and city; lot number; individual characteristics of oil paintings, specifically, name, height, width, signature, exhibitions, references in literature; hammer price, low and high auction's price estimations. Prices and auction's assessments have been adjusted for inflation based on CPI index. We also add some other indicators such as macroeconomic region, group of the author's nationality, art sector, the artist's rating according to http://artprice.com

As a matter of fact there is a small 1-5\% layer of "masterpieces" sold for millions of dollars and other artworks which price amounts about only $\$ 10000-\$ 50000$. As we can see from Fig. 1, the distribution of prices is highly skewed even if we take price logarithms.

\section{Methodology}

To model prices on the fine art market we apply the hedonic approach, which implies that an individual optimizes the consumption choosing a product with an optimal set of parameters subject to a budget constraint. It means that her choice depends on income and implicit "prices" of the characteristics, which are estimations of differences between item's qualities in value terms Taking into account the high level of art prices heterogeneity we use quantile regression for each fine art market sector. Further we evaluate price indices for each estimated quantile and compare the results with the stock market performance represented by S\&P 500 . And finally, based on the hedonic regression, we obtain the art market returns and estimate risk associated with them via CAPM model.

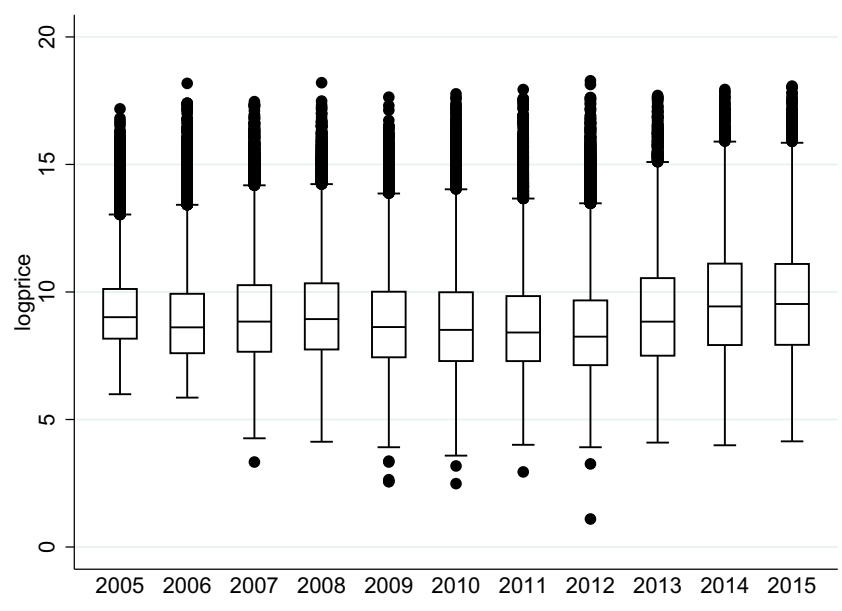

Fig. 1. Box plot for the price logarithm

\section{A. Price modeling}

The hedonic approach to price modeling was first introduced by Andrew Court in [13] and [14] and revisited in [15]. According to the basics of the hedonic approach the commodity price can be explained by the characteristics fixed in time and time-varying ones. We use semi-log representation of the price equation as in (1).

$$
\begin{aligned}
& \ln p_{i t}= \\
& \sum_{a=1}^{A} \alpha_{a} \cdot X_{a i}+\sum_{t=1}^{T} \sum_{b=1}^{B} \beta_{b} \cdot Z_{b i t}+\sum_{t=1}^{T} \gamma_{t} \cdot D_{t}+\varepsilon_{i t},
\end{aligned}
$$

where $p_{i t}$ - the sale price. It depends on individual characteristics, which are fixed in time $\left(X_{a i}\right)$ and time varying $\left(Z_{b i t}\right)$, and time trend characterized by the sum of dummyvariables $\left(D_{i t}\right)$ constructed for each year or month. The random term $\varepsilon_{i t}$ follows normal distribution with zero mean and variance $\sigma^{2}$.

Equation (1) is estimated by simple quantile regression (see, for example, [16]). The coefficient estimates for (1) are obtained as in (2).

$$
\begin{gathered}
\hat{\beta}=\arg \min _{\beta \in R^{B}} \sum_{i=1}^{N} \sum_{t=1}^{T}\left(w_{\tau} \cdot\left(p_{i t}-\hat{p}_{i t}\right)\right), \\
w_{\tau}=\left\{\begin{array}{cc}
\tau, & p_{i t} \geq \hat{p}_{i t}, \\
1-\tau, & p_{i t}<\hat{p}_{i t} .
\end{array}\right.
\end{gathered}
$$

We estimated (2) for $\tau$ equals to $0.25,0.50$ and 0.75 .

For constructing the price index we use so called "time dummy variable method" (for details see, for example, [17]). The price index is calculated as in (3).

$$
\operatorname{Ind}_{t}=\exp \left(\gamma_{t}\right)
$$

where $\gamma_{t}$ is taken from (1).

\section{B. Risk evaluation}

In order to evaluate the risk attributed to the fine art market we propose to estimate a CAPM model (see, for example, [18]), where the treasure bills rate is used as a risk-free rate 

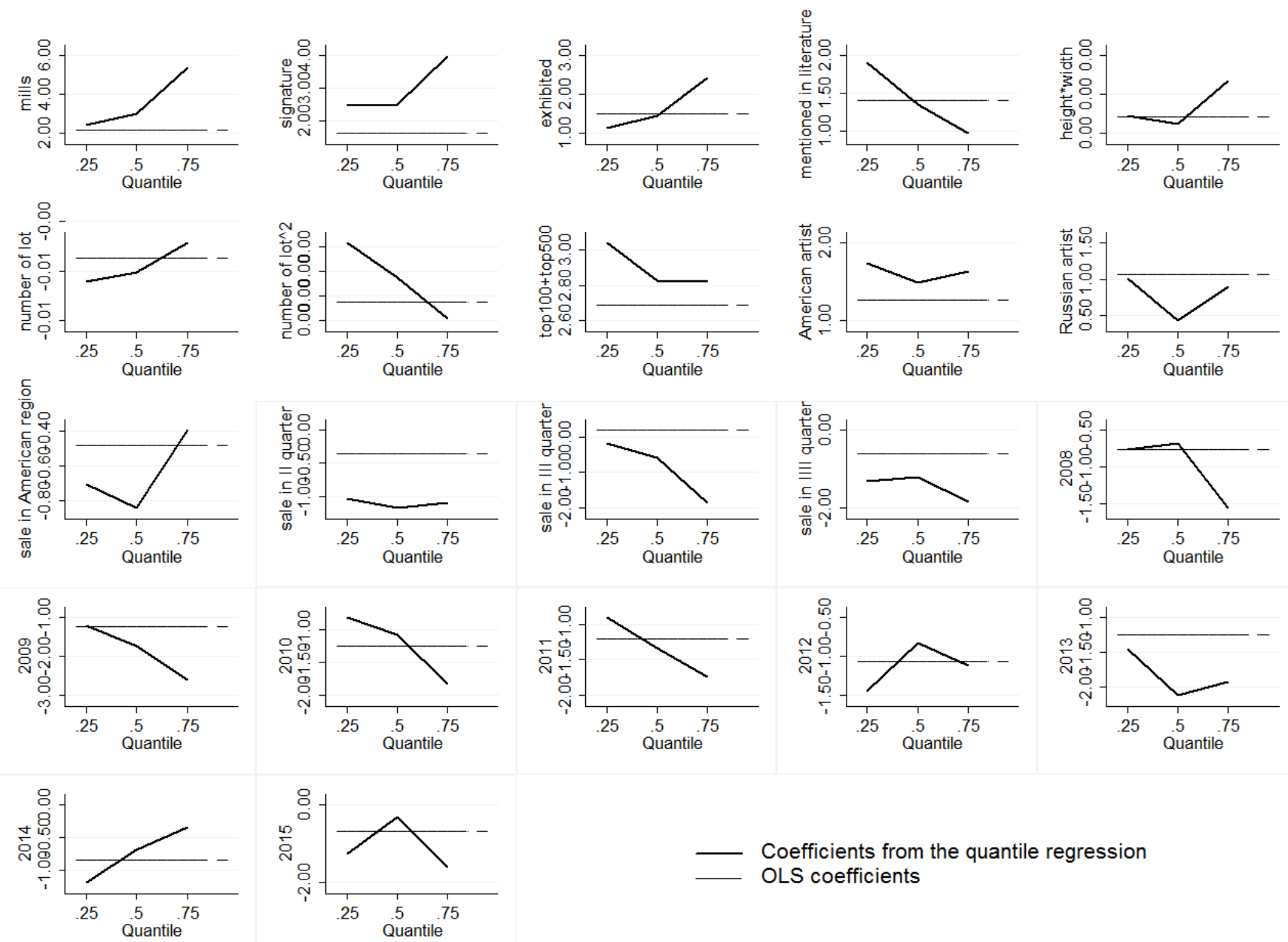

Fig. 2. Comparison between coefficients from quantile regression with sample selection and OLS for the modern art

$R_{f}$, and the S\&P500 index represents stock market returns $R_{m}$, (4).

$$
E\left(R_{t}\right)-R_{f}=\beta_{\tau}\left(E\left(R_{m}\right)-R_{f}\right), t=1, \ldots, T
$$

We obtain fine art market returns $R_{t}$ by relating current price index value to the same with one lag. The CAPM model is also estimated for each art sector and price quantile in order to obtain comparable inferences.

\section{EMPIRICAL RESULTS}

At the first step of our investigation we estimate (1) by OLS for each sector on the fine art market.

Comparing the results from quantile regression with OLS, we come to the conclusion that the estimates vary by quantiles considerably. As an example, the coefficients estimated for the modern art sector are shown on Fig. 2. According to Fig. 2, the OLS approach significantly underestimates the impact of some factors and overestimates the influence of other ones. Moreover, signs of coefficients in the quantile regression are more consistent with theoretical assumptions ${ }^{3}$. The results for

\footnotetext{
${ }^{3}$ It's worth mentioning that we also analyse price equation (1) with sample selection applying Heckman model [19] and quantile regression with sample selection following [20]. Taking into account the selection procedure does not contribute to the explanation of art prices.
}

modern and postwar art are presented in details in Table $\mathrm{I}^{4}$.

Further, we estimated an extended specification of the model (1), using quantile regression, in order to obtain a monthly hedonic index. In particular, we add dummy variables for each month of the period 2007-2015 (a basic variable is January of 2007). As an example, Figure 3 presents the resulted index for impressionism in comparison with S\&P500 index. According to them, art indexes constructed for different sectors as well as for different quantiles demonstrate diverse behavior. Firstly, the higher the quantile is the greater variation attributes to the index; this observation is true for all paintings from old masters artworks to the contemporary art. Secondly, the least stable sector is the contemporary art, what is in accordance with our expectations: the prices in the sector have experienced high fluctuations before and after the crisis. For example, in 2008 the prices soared by 8 times compared the beginning of the previous year. Moreover, all five patterns clearly show the negative effect of the crisis on the market, what is reflected in the lower values of art price indexes.

In addition, comparing with the S\&P 500 index, we could

\footnotetext{
${ }^{4}$ For the sake of space saving we do not present the estimates of quantile regression for old masters art, impressionism and contemporary art. These results are available upon the request.
} 
TABLE I

THE RESULTS FROM THE QUANTILE REGRESSION (OLD MASTERS ART AND IMPRESSIONISM)

\begin{tabular}{|c|c|c|c|c|c|c|}
\hline \multirow{3}{*}{ Variables } & \multicolumn{6}{|c|}{ Sectors } \\
\hline & \multicolumn{3}{|c|}{ Old } & \multicolumn{3}{|c|}{ Impressionism } \\
\hline & $\mathrm{q} 25$ & q50 & q75 & $\mathrm{q} 25$ & q50 & q75 \\
\hline author's signature & $\begin{array}{c}0.0275 \\
(1.29)\end{array}$ & $\begin{array}{c}0.0645 * * \\
(2.59)\end{array}$ & $\begin{array}{l}0.0887 * * * \\
(3.54)\end{array}$ & $\begin{array}{l}-0.0154 \\
(-0.71)\end{array}$ & $\begin{array}{l}-0.0323 \\
(-1.43)\end{array}$ & $\begin{array}{c}-0.0828^{*} \\
(-2.45)\end{array}$ \\
\hline painting was exhibited & $\begin{array}{l}0.4843 * * * \\
(8.18)\end{array}$ & $\begin{array}{l}0.6243 * * * \\
(9.50)\end{array}$ & $\begin{array}{c}0.7258^{* * *} \\
(13.28)\end{array}$ & $\begin{array}{c}1.0925 * * * \\
(31.70)\end{array}$ & $\begin{array}{l}1.0054 * * * \\
(21.58)\end{array}$ & $\begin{array}{l}0.9548^{* * * *} \\
(21.14)\end{array}$ \\
\hline painting was mentioned in literature & $\begin{array}{c}0.9581 * * * \\
(25.52)\end{array}$ & $\begin{array}{c}0.9439 * * * \\
(22.65)\end{array}$ & $\begin{array}{c}0.9890 * * * \\
(23.71)\end{array}$ & $\begin{array}{c}1.1866 * * * \\
(28.52)\end{array}$ & $\begin{array}{c}1.3199 * * * \\
(40.55)\end{array}$ & $\begin{array}{c}1.3460 * * * \\
(42.68)\end{array}$ \\
\hline height $\times$ width & $\begin{array}{c}0.0001 * * * \\
(11.75)\end{array}$ & $\begin{array}{c}0.0001 * * * \\
(10.55)\end{array}$ & $\begin{array}{l}0.0000 * * * \\
(9.23)\end{array}$ & $\begin{array}{c}0.0001 * * * \\
(18.86)\end{array}$ & $\begin{array}{c}0.0001 * * * \\
(19.68)\end{array}$ & $\begin{array}{l}0.0001 \text { *** } \\
(34.29)\end{array}$ \\
\hline$(\text { height } \times \text { width })^{2}$ & $\begin{array}{c}-0.0000 * * * \\
(-3.96)\end{array}$ & $\begin{array}{c}-0.0000^{* *} \\
(-3.06)\end{array}$ & $\begin{array}{c}0 \\
(-1.42)\end{array}$ & $\begin{array}{c}-0.0000 * * * \\
(-5.09)\end{array}$ & $\begin{array}{c}-0.0000^{* * * *} \\
(-4.00)\end{array}$ & $\begin{array}{c}-0.0000 * * * \\
(-5.22)\end{array}$ \\
\hline number of lot & $\begin{array}{c}-0.0001 \\
(-1.11)\end{array}$ & $\begin{array}{c}-0.0008^{* * * *} \\
(-6.10)\end{array}$ & $\begin{array}{c}-0.0019 * * * \\
(-11.61)\end{array}$ & $\begin{array}{c}-0.0010 * * * \\
(-18.28)\end{array}$ & $\begin{array}{c}-0.0012 * * * \\
(-19.60)\end{array}$ & $\begin{array}{c}-0.0015^{* * *} * \\
(-21.94)\end{array}$ \\
\hline number of $\operatorname{lot}^{2}$ & $\begin{array}{c}0.0000^{* * *} \\
(2.63)\end{array}$ & $\begin{array}{c}0.0000^{* * * *} \\
(7.13)\end{array}$ & $\begin{array}{c}0.0000 * * * \\
(9.57)\end{array}$ & $\begin{array}{c}0.0000 * * * \\
(15.46)\end{array}$ & $\begin{array}{c}0.0000^{* * * *} \\
(16.42)\end{array}$ & $\begin{array}{c}0.0000 * * * \\
(21.60)\end{array}$ \\
\hline top 100 & $\begin{array}{c}1.9373^{* * *} \\
(12.47)\end{array}$ & $\begin{array}{c}1.9409^{* * *} \\
(20.75)\end{array}$ & $\begin{array}{c}1.9195^{* * *} \\
(9.69)\end{array}$ & $\begin{array}{c}3.0084 * * * \\
(71.89)\end{array}$ & $\begin{array}{c}3.0049 * * * \\
(67.42)\end{array}$ & $\begin{array}{c}3.0061 * * * \\
(60.22)\end{array}$ \\
\hline top 500 & $\begin{array}{c}1.4088 * * * \\
(27.51)\end{array}$ & $\begin{array}{c}1.3701 * * * * \\
(25.90)\end{array}$ & $\begin{array}{c}1.4420 * * * \\
(23.66)\end{array}$ & $\begin{array}{c}1.6053^{* * *} * \\
(44.03)\end{array}$ & $\begin{array}{c}1.6876^{* * * *} \\
(47.34)\end{array}$ & $\begin{array}{c}1.7392 * * * \\
(48.89)\end{array}$ \\
\hline Russian author & $\begin{array}{c}0.8814 \\
(1.96)\end{array}$ & $\begin{array}{c}1.0591^{*} \\
(2.47)\end{array}$ & $\begin{array}{c}1.0310^{*} \\
(2.38)\end{array}$ & $\begin{array}{c}1.0740 * * * \\
(22.17)\end{array}$ & $\begin{array}{c}1.2063^{* * *} * \\
(24.74)\end{array}$ & $\begin{array}{c}1.1587 * * * \\
(21.49)\end{array}$ \\
\hline American author & $\begin{array}{c}-0.9303^{* * *} \\
(-5.15)\end{array}$ & $\begin{array}{c}-0.6831^{* *} \\
(-3.23)\end{array}$ & $\begin{array}{c}-0.6404^{*} \\
(-2.24)\end{array}$ & $\begin{array}{l}0.0017 \\
(0.05)\end{array}$ & $\begin{array}{l}0.0476 \\
(1.65)\end{array}$ & $\begin{array}{l}0.1069^{* * *} \\
\quad(3.56)\end{array}$ \\
\hline Latin American author & & & & $\begin{array}{c}1.3171 * * * \\
(8.86)\end{array}$ & $\begin{array}{c}1.4530 * * * \\
(7.16)\end{array}$ & $\begin{array}{c}1.3695 * * * \\
(6.04)\end{array}$ \\
\hline sale in II quarter & $\begin{array}{c}0.0626 \\
(1.58)\end{array}$ & $\begin{array}{l}-0.061 \\
(-1.45)\end{array}$ & $\begin{array}{c}-0.1267 * * \\
(-2.83)\end{array}$ & $\begin{array}{c}0.3343^{* * *} \\
(17.96)\end{array}$ & $\begin{array}{c}0.4503^{* * *} * \\
(24.91)\end{array}$ & $\begin{array}{c}0.5110 * * * \\
(17.53)\end{array}$ \\
\hline sale in III quarter & $\begin{array}{l}0.2762 * * * \\
\quad(5.96)\end{array}$ & $\begin{array}{l}0.3176 * * * \\
(6.23)\end{array}$ & $\begin{array}{l}0.4762 * * * \\
(9.33)\end{array}$ & $\begin{array}{c}-0.0348 \\
(-1.56)\end{array}$ & $\begin{array}{r}-0.0317 \\
(-1.45)\end{array}$ & $\begin{array}{r}-0.0145 \\
(-0.40)\end{array}$ \\
\hline sale in IIII quarter & $\begin{array}{l}0.0044 \\
(0.10)\end{array}$ & $\begin{array}{r}-0.0813 \\
(-1.61)\end{array}$ & $\begin{array}{c}-0.0814 \\
(-1.54)\end{array}$ & $\begin{array}{c}0.1720 * * * \\
(11.53)\end{array}$ & $\begin{array}{l}0.2322 * * * \\
(11.96)\end{array}$ & $\begin{array}{l}0.3082 * * * \\
(10.18)\end{array}$ \\
\hline 2008 & $\begin{array}{c}0.0296 \\
(0.75)\end{array}$ & $\begin{array}{c}0.0442 \\
(1.38)\end{array}$ & $\begin{array}{c}0.0018 \\
(0.05)\end{array}$ & $\begin{array}{c}0.0562 * * \\
(2.68)\end{array}$ & $\begin{array}{c}-0.0011 \\
(-0.06)\end{array}$ & $\begin{array}{c}-0.0017 \\
(-0.09)\end{array}$ \\
\hline 2009 & $\begin{array}{c}-0.2174 * * * \\
(-5.62)\end{array}$ & $\begin{array}{c}-0.1969 * * * \\
(-5.60)\end{array}$ & $\begin{array}{c}-0.2405^{* * * *} \\
(-5.69)\end{array}$ & $\begin{array}{c}-0.2248 * * * \\
(-6.98)\end{array}$ & $\begin{array}{c}-0.2632 * * * \\
(-9.25)\end{array}$ & $\begin{array}{c}-0.3064 * * * \\
(-10.37)\end{array}$ \\
\hline 2010 & $\begin{array}{l}-0.2329 * * * \\
\quad(-6.10)\end{array}$ & $\begin{array}{c}-0.2062 * * * \\
(-6.73)\end{array}$ & $\begin{array}{c}-0.2263^{* * *} \\
(-6.64)\end{array}$ & $\begin{array}{c}-0.3176^{* * * *} \\
(-10.71)\end{array}$ & $\begin{array}{c}-0.3436^{* * *} \\
(-12.14)\end{array}$ & $\begin{array}{c}-0.3692^{* * * *} \\
(-12.48)\end{array}$ \\
\hline 2011 & $\begin{array}{l}-0.2222 * * * \\
\quad(-9.86)\end{array}$ & $\begin{array}{c}-0.1419^{* * * *} \\
(-6.05)\end{array}$ & $\begin{array}{c}-0.1324 * * * \\
(-3.98)\end{array}$ & $\begin{array}{c}-0.3022 * * * \\
(-13.02)\end{array}$ & $\begin{array}{c}-0.3438 * * * \\
(-14.17)\end{array}$ & $\begin{array}{c}-0.3515^{* * * *} \\
(-10.63)\end{array}$ \\
\hline 2012 & $\begin{array}{c}-0.2564 * * * \\
(-4.74)\end{array}$ & $\begin{array}{c}-0.1895 * * * \\
(-3.91)\end{array}$ & $\begin{array}{c}-0.0778 \\
(-1.31)\end{array}$ & $\begin{array}{c}-0.4691 * * * \\
(-17.77)\end{array}$ & $\begin{array}{c}-0.4833 * * * \\
(-19.37)\end{array}$ & $\begin{array}{c}-0.4739 * * * \\
(-14.14)\end{array}$ \\
\hline 2013 & $-0.1177 *$ & $\begin{array}{c}-0.02 \\
(-0.39)\end{array}$ & $\begin{array}{c}0.1306^{*} \\
(2.27)\end{array}$ & $\begin{array}{c}-0.2753 * * * \\
(-8.01)\end{array}$ & $\begin{array}{c}-0.2736 * * * \\
(-8.32)\end{array}$ & $\begin{array}{c}-0.2537 * * * * \\
(-7.28)\end{array}$ \\
\hline 2014 & $\begin{array}{l}0.031 \\
(0.48)\end{array}$ & $\begin{array}{l}0.1624 * * \\
(3.04)\end{array}$ & $\begin{array}{l}0.4096^{* * *} \\
(7.04)\end{array}$ & $\begin{array}{c}-0.1528 * * * \\
(-3.85)\end{array}$ & $\begin{array}{c}-0.1105^{*} \\
(-2.47)\end{array}$ & $\begin{array}{c}-0.1197^{*} \\
(-2.55)\end{array}$ \\
\hline 2015 & $\begin{array}{c}-0.1594 * * \\
(-2.58)\end{array}$ & $\begin{array}{c}-0.0442 \\
(-0.82)\end{array}$ & $\begin{array}{c}-0.0259 \\
(-0.58)\end{array}$ & $\begin{array}{c}-0.3035 * * * \\
(-9.97)\end{array}$ & $\begin{array}{c}-0.2846^{* * * *} \\
(-9.15)\end{array}$ & $\begin{array}{c}-0.2956 * * * \\
(-7.18)\end{array}$ \\
\hline sale in Asia region & & & & $\begin{array}{c}1.3045 * * * \\
(5.46)\end{array}$ & $\begin{array}{c}1.5055^{* * *} * \\
(14.07)\end{array}$ & $\begin{array}{c}1.1092 * * * \\
(9.29)\end{array}$ \\
\hline sale in Oceania region & & & & $\begin{array}{c}-0.6872 * * * \\
(-4.35)\end{array}$ & $\begin{array}{c}-0.9388 * * * \\
(-4.39)\end{array}$ & $\begin{array}{c}-0.8710^{* * *} \\
(-3.20)\end{array}$ \\
\hline sale in American region & $\begin{array}{c}0.4710^{* * *} \\
(10.36)\end{array}$ & $\begin{array}{c}0.5387 * * * \\
(10.60)\end{array}$ & $\begin{array}{c}0.6420 * * * \\
(14.37)\end{array}$ & $\begin{array}{c}0.3048 * * * \\
(15.39)\end{array}$ & $\begin{array}{l}0.4666 * * * \\
(18.73)\end{array}$ & $\begin{array}{l}0.6430 * * * \\
(25.05)\end{array}$ \\
\hline sale in a capital & $\begin{array}{c}0.5123 * * * \\
(13.87)\end{array}$ & $\begin{array}{c}0.4189 * * * \\
(9.22)\end{array}$ & $\begin{array}{c}0.3316^{* * * *} \\
(7.29)\end{array}$ & $\begin{array}{c}0.3394 * * * \\
(17.83)\end{array}$ & $\begin{array}{c}0.4571 * * * \\
(21.84)\end{array}$ & $\begin{array}{c}0.5681 * * * \\
(29.24)\end{array}$ \\
\hline constant & $\begin{array}{c}8.2344 * * * \\
(117.41)\end{array}$ & $\begin{array}{c}9.2592 * * * \\
(112.33)\end{array}$ & $\begin{array}{c}10.3364 * * * \\
(136.97)\end{array}$ & $\begin{array}{c}7.2171 * * * \\
(276.65)\end{array}$ & $\begin{array}{c}7.9570 * * * \\
(272.11)\end{array}$ & $\begin{array}{c}8.8252 * * * \\
(214.07)\end{array}$ \\
\hline $\begin{array}{l}\text { Number of observations } \\
\text { pseudo R-sq }\end{array}$ & 0.1499 & $\begin{array}{r}20088 \\
0.1571\end{array}$ & 0.1799 & 0.1919 & $\begin{array}{l}61529 \\
0.2326\end{array}$ & 0.2769 \\
\hline
\end{tabular}

Symbols: * $-5 \%$ level of significance, $* *-1 \%$ level of significance, $* * *-0.1 \%$ level of significance;

standard errors in parenthesis. 


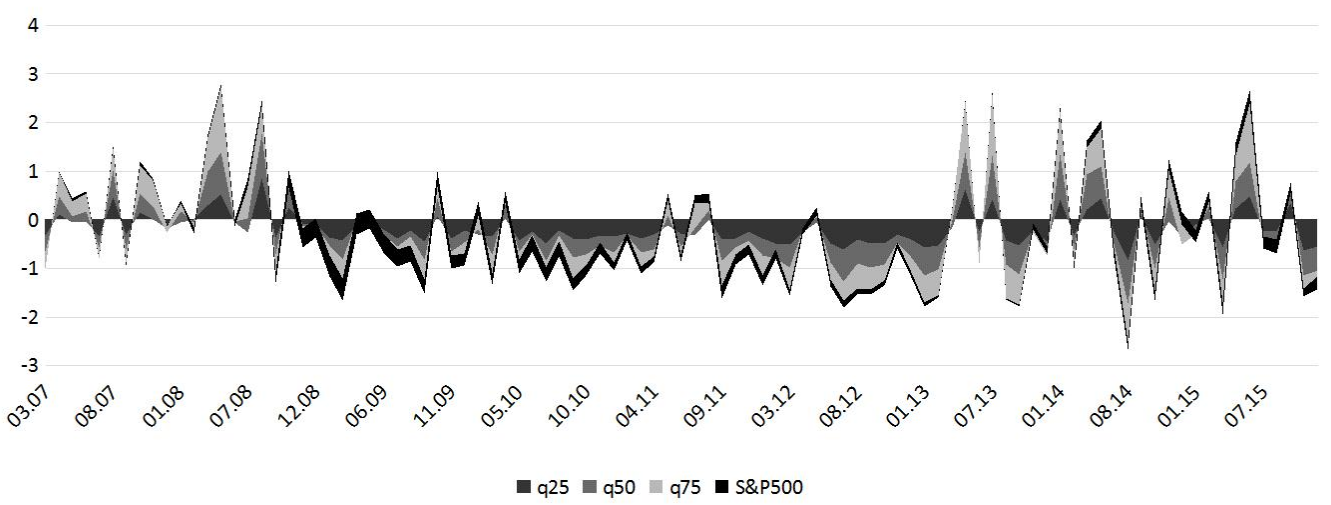

Fig. 3. Cumulative dynamics of the art price index constructed for the impressionism

TABLE II

SUMMARY STATISTICS ON THE ART RETURNS AND THEIR DISPERSION

\begin{tabular}{|c|c|c|c|c|c|}
\hline Indicator & Old masters & Impressionism & Modern Art & Postwar Art & Contemporary Art \\
\hline \multicolumn{6}{|c|}{ OLS } \\
\hline Average return of all paintings & $-19.76 \%$ & $8.01 \%$ & $60.80 \%$ & $90.39 \%$ & $79.23 \%$ \\
\hline Dispersion of returns & 0.233 & 0.181 & 0.484 & 0.654 & 1.095 \\
\hline $\begin{array}{l}\text { Average return of paintings } \\
\text { under } 10000 \$\end{array}$ & $-1.46 \%$ & $-13.17 \%$ & $5.96 \%$ & $10.54 \%$ & $20.81 \%$ \\
\hline Dispersion of returns & 0.061 & 0.042 & 0.049 & 0.058 & 0.099 \\
\hline \multicolumn{6}{|c|}{ Quantile regression (0.25 quantile) } \\
\hline Average return & $-1.91 \%$ & $-19.20 \%$ & $-21.51 \%$ & $-14.03 \%$ & $-5.45 \%$ \\
\hline Dispersion of returns & 0.24 & 0.097 & 0.144 & 0.121 & 0.305 \\
\hline \multicolumn{6}{|c|}{ Quantile regression (0.50 quantile) } \\
\hline Average return & $-4.06 \%$ & $-6.00 \%$ & $-1.32 \%$ & $0.36 \%$ & $4.92 \%$ \\
\hline Dispersion of returns & 0.299 & 0.16 & 0.214 & 0.2 & 0.458 \\
\hline \multicolumn{6}{|c|}{ Quantile regression (0.75 quantile) } \\
\hline Average return & $0.21 \%$ & $1.95 \%$ & $20.51 \%$ & $24.63 \%$ & $20.71 \%$ \\
\hline Dispersion of returns & 0.438 & 0.218 & 0.337 & 0.306 & 1.113 \\
\hline
\end{tabular}

highlight two tendencies: relatively higher index range on the art market compared to the stock one and similar trends of art and stock indicators. The comparison of art market returns and stocks is a widespread tool of analysis among researchers. The recent study of [21] provides evidence that the confidential intervals for correlation between art returns and S\&P 500 are too wide, so, the merits of adding art assets to stock portfolios as a way of diversification are doubtful. Such inference does not contradict the pattern we demonstrate above.

Table II provides summary statistics for the calculated indexes. The OLS approach leads to index values that are far from theoretical expectations. This is caused by the fact that record prices of "masterpieces" bias the price index, and as a consequence overestimate the result. This problem could be partly solved by considering only paintings under certain price, making the data more homogeneous. We estimate the model on a restricted sample, which contains only oil paintings under $\$ 10000$. Despite this, the variance of the index is too high even under restriction. On the other hand, the average return on the modern art market is close enough to the results from other studies in this field [12], [22].

The quantile regression allows us to get a more complete pattern of the fine art market. The inference implies that prices of the cheapest artworks have decreased significantly since January of 2007, especially, the price for the modern art. The situation is better considering the median regression. The best returns are presented in the 0.75 quantile, which means that prices of the most expensive paintings have gone up significantly. In this case the most attractive sector is postwar art market because it has the highest value of the average price index and lower dispersion of the index comparing with the contemporary art which is the most speculative sector as we can see (however [23] argue that all segments - "Impressionist and Modern", "Post-war and Contemporary", "American" and "Old Masters" - are likely to demonstrate the speculative behaviors, if they are compared with other markets). The art of old masters along with impressionism is not very interesting for investors.

The hypothesis that more expensive artworks have a higher return along with a higher risk is proved by the result obtained from estimating the simple CAPM equation. This approach to measuring the risk on the fine art market is proposed by a number of studies [5], [10], [12], [22]. The values of beta are shown on the Figure 4. Thus, the more expensive the product is the more risky asset it is. Among five sectors the least risky is the Impressionists art, the most risky - the contemporary art. 


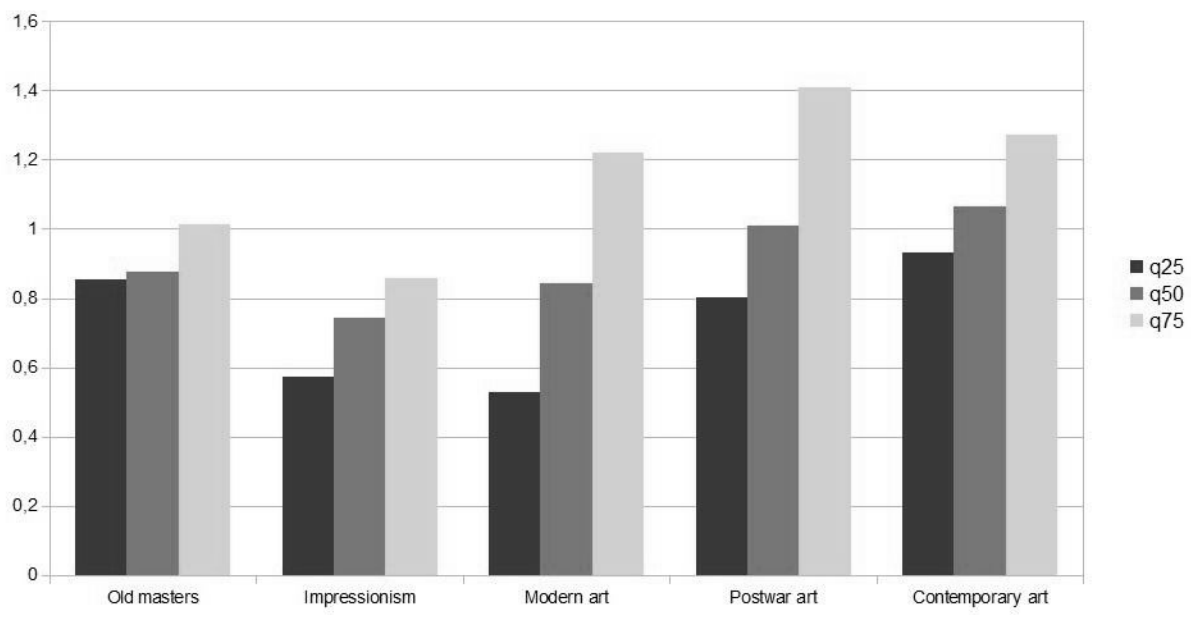

Fig. 4. Beta from the CAPM equation

\section{CONCLUSION}

The study represents an additional step toward understanding the investment potential of the fine art market. Investing in the fine art market is regarded as an alternative to the classical instruments of investment. Considering weak relations between art and stock markets, the purchase of works of art can serve to portfolio diversification. At the same time peculiar properties and specific risks connected with artworks should be taken into account.

In this paper we focus on oil paintings as the most representative product on the art market, the period of observation is 2005-2015. The data analysis confirms the high level of heterogeneity even upon consideration of oil paintings only. The analysis indicates that prices for a small stratum of "masterpieces" exceed other art works many times; parameters considered in the study demonstrate a different behavior at the art sectors level; we could also provide evidence of the 2008 crisis impact on the art market.

The econometric analysis reveals that the most appropriate method is the quantile regression as it allows taking into account the fact that the market effects differ depending on the price quantile. According to the estimation results, the postwar paintings sold in the high price sector could be considered as an attractive sector for the investors but its acquisition is accompanied by a relatively high risk compared to the operation on the stock market. The paintings of the low price sector are characterized by a lower risk but the prices for such paintings tend to go down the last ten years.

\section{REFERENCES}

[1] D. Vincent, "Bidding off the wall: why reserve prices may be kept secret," Journal of Economic Theory, vol. 65(2), pp. 575-584, 1995.

[2] O. Ashenfelter, K. Graddy, "Sale rates and price movements in art auctions," Working Papers, Princeton University, vol. 1294, 2011.

[3] O. Ashenfelter, K. Graddy, "Art auctions: a survey of empirical studies," NBER working paper series, vol. 8997, p. 43, 2002.

[4] A. Beggs, K. Graddy, "Failure to meet the reserve price: the impact on returns to art," Discussion Paper Series, Oxford, vol. 272, 2006.

[5] J. E. Pesando, "Art as an investment. The market for modern prints," American Economic Review, vol. 83, pp. 1075-1089, 1993.
[6] W. Goetzmann, L. Renneboog, C. Spaenjers, "Art and Money," American Economic Review, vol. 101(3), pp. 222-226, 2011.

[7] A. Beggs, K. Graddy, "Anchoring effects: evidence from art auctions," Economic Review, vol. 99(3), pp. 1027-1039, 2009.

[8] Campbell, Rachel AJ, "Art as a financial investment," The Journal of Alternative Investments, vol. 10, no. 4. Euromoney Institutional Investor PLC, p.64, 2008.

[9] R.J. Agnello, "Investment returns and risk for art: evidence from auctions of American paintings," Eastern Economic Journal, vol. 28, pp. 443-463, 2002.

[10] J. E. Pesando, P. M. Shum, "The auction market for modern prints: confirmations, contradictions, and new puzzles," Economic Inquiry, vol. 46(2), pp. 149-159, 2008.

[11] O. Chanel, L. A. Gerard-Varet, V. Ginsburgh, "Prices and Returns on Paintings: An Exercise on How to Price the Priceless," The Geneva Papers on Risk and Insurance Theory, vol. 19, pp. 7-21, 1994.

[12] J. Mei, M. Moses, "Art as an investment and the underperformance of masterpieces," American Economic Review, vol. 92(5), pp. 1656-1668, 2002.

[13] Court, Louis M, "Entrepreneurial and Consumer Demand Theories for Commodity Spectra (Concluded)," Econometrica: Journal of the Econometric Society. JSTOR, pp. 241-297, 1941.

[14] Court, Louis M, "Entrepreneurial and Consumer Demand Theories for Commodity Spectra: Part I," Econometrica: Journal of the Econometric Society, vol. 44, no. 2. JSTOR, pp. 135-162, 1941.

[15] Goodman, Allen C, "Andrew Court and the invention of hedonic price analysis," Journal of urban economics, vol. 44, no. 2. Elsevier, pp. 291298, 1998.

[16] Koenker, Roger and Hallock, Kevin F, "Quantile regression,” Journal of economic perspectives, vol. 15, no. 4, pp. 143-156, 2001.

[17] Renneboog, Luc and Spaenjers, Christophe, "Buying beauty: On prices and returns in the art market," Management Science, vol. 59, no. 1. INFORMS, pp. 36-53, 2013.

[18] Fama, Eugene F and French, Kenneth R, "The capital asset pricing model: Theory and evidence," Journal of economic perspectives, vol. 18 , no. 3, pp. 25-46, 2004.

[19] Heckman, James J, "Sample Selection Bias as a Specification Error," Econometrica, vol. 47, no. 1, pp. 153-161, January, 1979.

[20] M. Bushinsky, "Quantile regression with sample selection: estimating women's return to education in the US," Empirical Economics, vol. 26, pp. 87-113, 2001.

[21] V. Charlin, A. Cifuentes, "On the correlation between stocks and art market returns," Applied Economics Letters, vol. 24(2), pp. 128-131, 2017

[22] O. Chanel, L. A. Gerard-Varet, S. Vincent, "Auction theory and practice: evidence from the market for jewellery," Economics of the Arts: Selected Essays, vol. 38(5), pp. 367-380, 1996.

[23] R. Kraussl, T. Lehnert, N. Martelin, "Is there is a bubble in the art market?," Journal of Empirical Finance, vol. 35, pp. 99-109, 2016. 